\title{
Inclusion in a Multicultural Nation: Realities through Case Studies
}

Vishalache Balakrishnan, PhD.

\author{
Post-doctoral Scholar
}

The University of Waikato

New Zealand

visha@waikato.ac.nz

visha@um.edu.my

\begin{abstract}
According to Inclusion Press International, inclusion is not just a 'disability issue' but about living full lives, about learning to live together and treasuring diversity and building community. When Malaysia obtained her independence from the Britain in 1957, one of the main ruling was all three ethnicity should live together as one nation. No individual should be excluded from any aspects of education, economy and social. After almost six decades of independence, many individuals in Malaysia are still unhappy with the social injustice due to exclusion based on several factors such as ethnicity and historical roots. In this paper I would like to argue that the minority ethnic group have been side lined due to constitutional rights and current policies. They have to fend for themselves and the social injustice caused many to leave their country of birth to move to other countries where they are treated equally for what they are and not who they are. I suggest that there is a critical need to overlook its political, economic and education policies to ensure a new world which is just and fair.
\end{abstract}

Keywords: multiculturalism, inclusive education, social injustice

\section{Introduction}

Inclusion in a multicultural nation is so important for the growth and development of the nation and its people. Inclusion here is seen from a broader perspective where inclusion is about all of us, about living full lives-about learning to live together, about making the world our classroom 
for a full life, about treasuring diversity and building community. Inclusion is about our 'abilities' - our gifts and how to share them (Inclusion Press International, 2015). Using Malaysia as an example of a multicultural nation where different ethnicities have been coexisting for centuries, I will be elaborating discourses of how several individuals and communities had been excluded in their lives. The narratives are mostly of individuals who left Malaysia, not because they were unpatriotic or did not like the country but more of exclusion practices which made them and their families and their communities felt neglected and isolated, discriminated and unrecognised. Until today there are majority of minority groups who feel they are treated as second class citizens, even though they are the third or fourth generation to be descending in Malaysia.

\section{How it all began}

I would start my paper with my own journey as an individual who was born in Malaysia in the 1960s. Growing up in a Chinese-Indian mix parentage family and living in a Catholic church environment which catered to the needs of the local community who were poor, I had the best multicultural environment. I knew I was different from the Chinese or the Indian girls but I made friends with every one as I was different. And I was easily accepted as I understood the Chinese and Indian culture well. I physically looked like a Malay girl so Malay students like to hang out with me. Differences attracts just like magnets and I had a wonderful start to my life in a multicultural nation.

Then when I started secondary school, I began to realise that I was not treated equally by the system. I was in a missionary school so the environment, the teachers and the school community were compassionate and nurturing. But not the system. I came to realise that my Malay friends who were poor or some better off than me received financial aid which I did not and they bluntly told me that it's only for Malay students. I felt the injustice but consoled myself by studying hard and performing well in my centralised examinations. Then came the next shock. In spite of getting distinction in English language, and most of the other subjects, I did not get any scholarships to pursue my studies overseas but almost all my Malay friends were offered scholarships to study TESL and other courses even though their grades were way below mine. Then I came to realise that I am different, I am not treated equally as my other friends and I accepted that as natural or even blamed myself for all the injustice that took place.

So I continued to pursue Sixth Form while most of my friends were overseas pursuing courses that some did not even qualify. I continued to teachers training college as my parents could not 
afford the fee for the local university. After becoming a trained teacher, I felt the injustice greater than ever, in the form of financial aid for students, academic equality and freedom of religion. All these made me very frustrated and made me want to further my studies to understand the system of the nation better and be part of a change for the better.

I continued with a special diploma course in TESL and again there was discrimination when selecting students to go overseas. It made me really angry and frustrated but I could not do much and continued to do my basic degree and my masters in a local university. It was after my masters that I decided to leave the school and join the university as this is where I could further research and analyse the social in(equality) that was in a nation I cherished. When I joined the university, I came to realise that even in the ivory tower, inequality and social injustice was so prevalent. It made me want to leave the country and look for greener pastures where people were recognised for their talent and skills and not their birth rights and who they were; but I loved my country and there was so much to do in my field which is moral education and citizenship education.

Thus I started initiating my own research, collaborated with international scholars and realised that many scholars from different parts of Asia and Africa shared similar experiences like what I had undergone. We are currently conducting a global research on inclusive policies and current inclusive practices in our own countries. We want to share our experiences and our research to the wider global world of what is written in policies and treaties and what is the actual inclusive practices in reality.

The case studies below were initiated through early discussions casually about Malaysia and where it was leading to as a multicultural nation. Most of the initial discussions had frustrated and anger tone with feelings of sadness, fear and doubt about Malaysia growing into a developed nation. However, as the discussions became deeper, there was a sense of ownership to what a multicultural nation was, is and will be. Participants and researcher have hope that past history might provide insights on overcoming injustice in a nation built on 'unity through diversity'.

\section{Methodology}

The research was conducted using a qualitative methodology; case studies. Case study is often seen as a means of gathering together data and providing coherence and limit to what is being 
sought (Hamilton, 2011). Data presented through case studies is usually gathered through several means such as interviews, observations, document collection, journal entry and many other ways which seems assessable with the current explosion of technology. An effort to manage researcher subjectivity as well as allowing the case to speak for itself (Stake, 2005) is what I have been exploring in this paper. Willig (2008), emphasises that case studies does not focus on methods used to collect and analyse data but more on analysing the case itself.

The case studies here are based on three individuals. Three individuals who are living in different parts of the world who were born and bred in Malaysia but left the country when they could not take the social injustice based on their personal experiences. Their personal journals which they wrote over a period of six to eight months about their lives in Malaysia and in comparative with their lives in their current country is analysed and discussed. I was in constant communication with them though digital technology means such as "WhatsApp", "Face Book", and emails. They agreed to be part of the research with the condition that their identity and their current place of stay is not disclosed.

\section{Case Study 1}

Orchid is a 49 year old female, belonging to the majority ethnicity group and religion. She grew up in a multicultural city environment, and went to a missionary school from primary to secondary school. Being a bright student, she was offered to do A levels and study medicine in one of the top universities in the United Kingdom. Here, Orchid met Shah who came from Iran and both of them got married in their final year of doing medicine. When Orchid brought Shah back to Malaysia to introduce him to her family and friends, she had a shock of her life. Their marriage was not considered legal as Shah belonged to another denomination of Islam and Malaysian Muslim authority only allows that particular denomination to be practiced in Malaysia. That was 25 years ago and the ruling still stays. Orchid has three children and her family lives in one of the European countries now. She is a practising Muslim and holds strongly to her faith. She can't come back to Malaysia as a family and finds the ruling absurd.

\section{Case Study 2}

Greg is a 48 year old male Malaysia who is currently leaving in a neighbouring country. Greg has always been a bright student since young and always tops his class in academic and also co-curriculum. When Grey completed his Sijil Pelajaran Malaysia which is equivalent to O levels in the UK, he scored straight A's in all the subjects he sat for and was confident of 
securing a federal scholarship as his parents were poor and could not afford to send him for higher education. Unfortunately for Greg, most of his friends from the majority ethnic group who did worse than him secured state and federal scholarships to further their studies in overseas universities. Greg applied to work in a neighbouring country to fend for himself and later to further his studies. Luckily for Greg, the interviewer at the factory where he applied for the job as a machine operator saw his excellent results and recommended him for a scholarship. Greg completed his studies up to masters and is currently serving the government of that country. In his blog, he expressed his frustrations of not being recognised by his own country but being welcomed by the neighbouring country. In recent years, there were calls for Malaysians abroad to come back and serve the country. Though Greg misses his family and friends back home, he said the system he was in was so unjust that he will not come back. He said he grew up with feelings of patriotism for the country but all was crushed when he faced the reality in equality of scholarships and opportunity to study.

\section{Case Study 3}

Fiona is a third generation immigrant to Malaysia. Her grandparents were plantation owners and had a tough head start, when they manually cleared the thick tropical jungles to plant crops. They were doing well with all the long hours of hard work put in. As the family grew bigger, they had more hand to help and were progressing well. However today, after three generations, Fiona and her brothers have sold their plantation and left the country for good with a heavy heart. They could not bear to leave but had little choice as their agricultural business was totally controlled by the majority ethnic group. They had to include the majority ethnic group into their business and without equal effort put in, Fiona and her family feel chested. Cheated of their hard work, cheated of their long term history and cheated of their lives. Fiona sees no future for her children and her generation to come. She left the country five years ago and lives in another country. Though not living a luxurious life as how she was, Fiona feel contented because she lives a "clean" and "honest" life. A life where she has a voice and included as an individual. A life where she does not have to abide to business rules which she feels is injustice and not right. She still missed her country of birth.

\section{Discussion}

The research concludes that none of the individuals researched ever thought of leaving their country, where they were born for another. They all grew up in a healthy multicultural environment where being different was accepted and appreciated. But as they went into 
secondary schools, they started observing the discrimination which was taking place such as placement of students in classes, offers of scholarships and different types of treatment for different ethnic groups, economic inequality and religious disparity.

\section{Religious disparity}

In Orchid's case (Case Study 1), it was not that she did not understand her religion nor the morality within her religion but because of the system within the country, there was chaos in her earlier married life and it came to the stage where her parents wanted to disown her. But until today, she is a practicing Muslim who does all her religious obligations such as praying five times a day, reciting the verses in the Quran and sending her children for religious classes. She feels that the injustice takes place due to the rule of law set by a limited number of individuals who take the religious laws and norms into their hands.

\section{Education disparity}

Where education is concerned, Malaysia has good theoretical governance of providing students from poor and vulnerable family background to reach out for higher education through grants and scholarships. However, in reality, quota systems according to ethnic groups and bad governance in implementing policies of education has made many individuals from minority ethnic groups and in several cases the majority ethnic group to leave the country. They are welcomed by other nations who treat then well for their talent and skills but feel discriminated in their own country of birth. In Greg's case (Case Study 2), he felt the inequality because of his ethnicity and the vulnerability of not being able to fight for his rights at an age where he was naïve and helpless. All he wanted was help him family go up the social mobility. But his ability, academic excellence and skills made him a prominent figure in another country, not his country of birth.

\section{Economic disparity}

Economic disparity is becoming more evident in current times as the pie is getting smaller and the people to feed is getting bigger. In Fiona's case (Case Study 3), the rules set to ensure balance in economic growth among the different ethnic groups have jeopardised her own family generation of hard work and progressiveness. She wanted to continue the agenda but felt the inequality was too much to digest. 


\section{Way Forward}

The Malaysia I knew of as a child and grew up as an adolescent and worked in as an adult and am researching critically as a social science researcher is still the same Malaysia it used to be. People are still multicultural, children still play with different ethnic groups, adolescents still hang out with friends of different ethnicity and religion, and adults still work with adults from other ethnicity. So why all the "huhas" about social injustice? Well, on the surface, everything looks picturesque and beautiful. But go a bit deeper and the truth slowly prevails.

Quota system according to ethnicity is something not accepted by most. Not even those who received privileges. Individuals were side lined due to who they were and not what their credibility was. Individuals leave the country because other countries were welcoming them for who they were and appreciated their talent and abilities. They could share their thoughts openly without being afraid of rule of law and other aspects within the constitution. Issues that all three participants highlighted as serious injustice were inequality in education, inequality in distribution of wealth and extremism of religiosity of the majority group that made them feel that freedom of religion as stated in the Federal Constitution is not practiced fully in reality. Their suggestion for the future of multicultural nation is a sound education system which embraces multicultural education and supports anti-bias curriculum in the school system to ensure that every one is included and no one is left behind. 


\section{Reference}

Hamilton, L. (2011) Case studies in educational research, British Educational Research Association on-line resource. Retrieved: https://www.bera.ac.uk/researchersresources/publications/case-studies-in-educational-research.

Stake, R. E. (2005). “Qualitative case studies.” In Denzin, Norman K. \& Lincoln, Yvonna S. eds. The sage handbook of qualitative research. 3rd ed. Thousand Oaks, CA: SAGE. pgs. 443-466.

Willig, C. (2008). Introducing qualitative research in psychology: Adventures in theory and method. London: Open University Press. 